\title{
Republicanism, socialism and the renewal of the left ${ }^{1}$
}

\author{
Martin McIvor
}

Recent soul-searching among the intellectual left has returned with increasing frequency and interest to implicitly or explicitly 'republican' themes and arguments. As class identities fracture, and state ownership falls into disrepute, republican conceptions of equal citizenship and the inherent value of a 'public realm' have appealed to many as potentially productive starting points for the left's ideological renewal.

This is not an especially new idea. As early as 1991, an important historical review of the Labour Party's roots in democratic movements of the nineteenth century suggested that 'the Labour Party's ability to play a leading role in broad progressive movements in the future will be strengthened if it becomes more restrained in its tendency to legitimise its policies primarily in relation to "socialism", and if it develops more self-consciousness of, and more pride in, its relation to currents of radicalism' (Biagini and Reid 1991: 19). But it has reappeared with increasing frequency of late. Gareth Stedman Jones has suggested that 'contemporary social democracy' should 'revisit its birthplace' of the late eighteenth century, when pioneering thinkers such as Paine and Condorcet sought to update 'a republican ideal of greater equality, inclusive citizenship and the public good' for modern times (Stedman Jones 2004: 245). Stuart White has asked if republicanism might now be 'the left's "big idea", and while concluding that its legacy is too complex to be reduced to a single, all-encompassing idea, is in no doubt that 'the idea of grounding social democracy in a republican conception of citizenship and the state is one we urgently need to rehabilitate' (White 2007: 44). David Marquand has argued that after the failure of its 'essentially paternalist model of social-democracy', 'what Labour now needs to do is revisit what I think of as the "democratic republican" strand in its heritage - the strand that goes back to Milton's thunderous prose and Tom Paine's magnificent audacity: the strand that emphasises self government by free and active citizens in a polity they own' (Marquand 2008). 
Broadly speaking, two key factors seem to lie behind this trend. One is the extraordinary wave of scholarly work, building since the 1970s and now a veritable academic 'industry', that has sought to recover a republican intellectual heritage and develop it for contemporary purposes. Historians inspired by the pioneering work of Quentin Skinner and J. G. A. Pocock have brought to light a tradition of political thought that had hitherto been somewhat hidden from view, a tradition of civic republican ideas that, drawing on classical sources, was revived at the time of the Renaissance and went on to influence the English radicalism of the seventeenth century, the American and French revolutions of the eighteenth century, and the great nationalist and democratic movements of the nineteenth century. Innovative political theorists such as Philip Pettit have drawn on this work to propose the continuing relevance and value of republican ideas and arguments as offering a powerful theoretical alternative to both 'liberal' and 'communitarian' political philosophies. ${ }^{2}$

Second, the specific contours of the contemporary 'conjuncture' mean that these ideas have proved particularly attractive to a left that is struggling to redefine its project after the collapse of state socialism and the declining appeal of a top-down, bureaucratic corporatism and welfarism, and to respond to widespread concerns about the deteriorating social fabric and 'hollowed-out' politics of the contemporary market societies that neo-liberalism is creating. Republican ideas seem to promise a route back to the values of freedom and democracy that the twentieth-century left seemed too often to lose touch with, at the same time as offering a viable and sophisticated defence of political activism and social commitment that could prove newly resonant for contemporary audiences. Nor has this been a purely academic or intellectual phenomenon - the renewed currency of republican values and concepts has begun to infuse contemporary policy debates around constitutional reform, the importance of 'civil society', and extending, as we shall see, to suggest new rationales for reforms aimed at securing greater social and economic equality. As Chapter 5 in this volume shows, the possibility that a reconstructed republicanism might offer a viable governing philosophy for twenty-first century social democracy has been taken up with particular enthusiasm by the Spanish Socialists, who went so far as to invite Philip Pettit to assess their performance against his own republican principles.

In this chapter, I want to welcome and endorse this republican revival, but also to sound a note of qualification or caution. It seems to me that the left today can find much nourishment in a recovery of its republican inheritance. But I want also to suggest reasons for thinking that there may be something inherently unstable about this set of ideas, that they have proved increasingly inadequate to the realities of modern societies 
and modern economies, and that in this sense the left's shift of focus from republican concerns to socialist and social democratic ambitions in the later nineteenth and earlier twentieth centuries was to some degree well motivated. This is not to argue that we can simply revert to the old values and forms of 'industrial' collectivism - for there is no doubt that they too came undone in a losing confrontation with social and economic change in the later twentieth century. But it is to argue that the difficult relationship between republican objectives and more ambitious and challenging forms of collectivism is one that the left must continue to grapple with.

A major caveat must be entered at this point: in surveying and critiquing historical and contemporary arguments around the relationship between republican and socialist ideas, this article can be only a sketch, and a necessarily crude one, unable to do justice to the historical complexities and philosophical nuances buried within this literature. My hope is that by taking such a broad view, at the expense of subtlety or detail, overarching continuities and recurrent issues come into view. But that will of course be for the reader to judge.

\section{Liberty as self-government}

The central starting point for the most influential reconstructions of the republican paradigm is the critique of arbitrary power, to which is opposed a particular ideal of freedom. According to Quentin Skinner, this idea can be traced back to the basic distinction in Roman law between a free man and a slave, and is picked up and redeveloped as a key political idea in Europe in the early modern period (Skinner 1997). According to Philip Pettit, this notion of 'freedom as non-domination' offers a compelling alternative to the more familiar liberal idea of 'negative' freedom as 'non-interference' (Pettit 1999). Even if my freedom of action is not directly interfered with, I may be 'unfree' in republican terms if I remain at the mercy of another who might at any point choose to restrain me - just as a slave is no less a slave if his or her master is generous or benign. Domination is thus a predicament of dependence upon the will of another, while true liberty consists in self-government - a condition in which I can be judged the true author of my actions, because they issue directly from my own agency without reference to the approval or otherwise of another. This notion lay at the heart of early critiques of absolute monarchies as a form of domination or despotism, irrespective of the character and behaviour of the monarch. It was not because they always did interfere with our freedom, but because they always could, that such arrangements rendered us slaves. As Paine put it in his seminal defence of the French Revolution: 'It was not against Louis XVI but against the despotic principle of the government that the nation 
revolted ... All the tyrannies of former reigns, acted under that hereditary despotism, were still liable to be revived in the hands of a successor' (Paine 1998: 98). It is because of this that we must take an active interest in our governing arrangements, and play our full part as virtuous citizens - as the only reliable means of securing ourselves against arbitrary interference.

There is however a further important development of this thought, one which is arguably pivotal to republican political thinking but which often, I think, is symptomatically underexamined or underdeveloped in many contemporary accounts. It is important for what I will go on to say, so it is worth flagging up at this point. This is the thought that, in so far as individuals are inextricably interdependent as a result of their social natures (or, if you prefer, historically acquired needs and characteristics), liberty as self-government can only be attained collectively, through universal submission to a form of rule that can be accepted by all advancing a common good. This latter stipulation of course creates a whole host of possibilities and problems, but is, I think, the only way we can give force to the critique of arbitrary power that is the republican starting point - power that is not just unpredictable, but somehow irrational or without justification. My claim, then, is that an essential dimension of republican political thought is the difficult but necessary task of developing a theory of collective agency that is consistent with individual self-rule. Thus for Spinoza some form of political association was an inescapable consequence of our need for mutual protection and our desire for friendship or amicitia - an 'affective' interdependence that we cannot break but which, by means of our rational powers, we can at least comprehend and so master. In 1670 he wrote that 'in a state or kingdom where the weal of the whole people, and not that of the ruler, is the supreme law, obedience to the sovereign power does not make man a slave ... that state is the freest whose laws are founded on sound reason, so that every member of it may, if he will, be free, that is live with full consent under the entire guidance of reason' (Spinoza 2005: 206). And in the most famous version of this argument Rousseau, who proposed that our 'chains' of interdependence could be rendered 'legitimate', and so our natural freedom regained in a moral or socialised form, if we could 'find a form of association that will defend and protect the person and goods of each associate with the full common force, and by means of which each, uniting with all, nevertheless obeys only himself and remains as free as before' (Rousseau 1997: 49-50). This form of association was the social contract, under which each promises unconditional obedience to a general will which seeks only the interests of the whole.

This transition - from freedom as individual self-government to freedom as submission to a rationally or democratically determined collective interest - remains a startling and, to many, troubling step in the republican 
argument. Rousseau's contested status as an authentic representative of the republican tradition is an illustrative moot point - Pettit, for example, seems to want to draw a line here. ${ }^{3}$ There is no doubt that the idea of identifying a 'collective interest' in a democratic or rational way, such that one who submits to its rule may be said to be obeying only themselves, poses a daunting set of philosophical and practical problems, and it is immediately obvious how such a proposal must be perilously vulnerable to misappropriation or abuse. But the point seen clearly by Spinoza and Rousseau, and too often evaded in contemporary appropriations of republican ideas, is that to the extent that we are dependent upon one another and cannot simply withdraw to our private, self-regarding spheres, this challenge is simply inescapable. The republican project is then not simply one of restraining the governing power to preserve our individual liberty, but also of pooling our liberty so that we might act together in pursuit of shared interests. One way of putting this point might be to assert that, to the extent that our fates are intertwined, the 'common good' to which our collective power is directed must be substantive and specific - not merely the formal principle of individual freedom from interference, but actual shared projects. ${ }^{4}$

\section{The passage from republicanism to socialism}

During the nineteenth century, republican political ideas about the forms of law and government were gradually displaced on the European left by a concern with economic relationships and ultimately a commitment to some notion of collective ownership of the means of production. Although most left movements and parties retained their commitment to democratic reforms, this was increasingly seen as an instrumental and relatively superficial precursor to more fundamental economic change. Sometimes this seems to express a degree of disillusionment and cynicism about the importance and value of 'politics' as such, in the name of a utilitarian concern with material living standards, a romantic commitment to a more profound social harmony, or an orthodox Marxist identification of the economic base as ultimately determinant (Bevir 2000). There is no doubt that these intellectual currents were influential, and that they diverted the left's agenda in ways that today seem unfortunate, perhaps fateful. Too many on the left seemed to have made the complacent assumption that the achievement of liberal, constitutional democracies allowed them to focus on other issues - meaning that the institutions they went on to build were undermined by the legitimate revolts of those in society - notably women and minorities - who were still far from receiving equal treatment and representation. ${ }^{5}$ But I want to suggest that there is another story to tell: about how socialist and social democratic ideas developed more logically 
and continuously from earlier republican agendas, the concerns of which they internalised and relocated. Briefly stated, it can be argued that as industrialisation and expanding trade extended and intensified the reality of interdependence, a consistent commitment to freedom from domination through collective self-government logically entailed attempts to bring the economy under collective democratic control.

Behind this story lies the traditional association of republican political ideas with predominantly agrarian economies that favoured relatively small-scale units of production and a significant degree of self-sufficiency. Although the preferred economic models of republican thinkers varied enormously - from Harrington's commonwealth of landowners to Rousseau's idealised peasant communities - a common theme was the notion that each owned enough to prevent dependence upon any other, but never so much more than others as to render others dependent. This restriction on material inequality secured for everyone the independence to act as a free citizen and guarded the republic against corruption or tyranny (White 2001).

But of course the growth of commercial trade and productive industry through the eighteenth and nineteenth centuries undermined the purchase, plausibility and appeal of this image of upright independence. The reality of modern economies has for the most part been an extension and intensification of interdependence - most individuals spend a measurably diminishing portion of their time acting or working for themselves in an unmediated way, and an increasingly predominant part of their time working to meet the needs of increasing numbers of others - either in response to market signals or under the command of an employer through whom the needs of the market are transmitted. And at the same time most individuals increasingly rely on the productive activities of increasing numbers of other individuals to meet their own developing needs. Some early writers warned against these developments - the American founding fathers worried about trends favouring inequality and the pursuit of luxury, and republican thinkers such as Price and Jefferson warned against the influence of commercial and manufacturing imperatives. Others, like Adam Smith, who celebrated this advancing division of labour, hoped that the rise of a commercially minded middle class might be reconciled with the preservation of civic virtues (Winch 2002). Indeed, for Smith the very spread of commerce served to unravel the ties of feudal power and servitude: "nothing tends so much to corrupt and enervate and debase the mind as dependency, and nothing gives such noble and generous notions of probity as freedom and independence. Commerce is one great preventative of this custom' (quoted by McNally 1993: 53).

But as David McNally has argued, Smith's 'model of commercial society 
based upon interaction between independent commodity producers like butchers, brewers and bakers' is in tension with the reality of modern Europe, in which as he acknowledges, 'the greater part of the workmen stand in need of a master' and wage-labourers outnumber independent workmen by a ratio of 20 to 1 (McNally 1993: 53-5). As Geoff Eley puts it, 'artisans increasingly lost control of their trades to the impersonal forces of the capitalist market. They surrendered the autonomy of the workshop to the practical forms of dependence on larger-scale business organization, before eventually becoming integrated directly into superordinate structures of capitalist production, employment, and control' (Eley 2002: 19-20). A recurrent argument of early socialists was that this economic dependence constituted a form of domination no less significant than the political domination of an unelected or unaccountable ruler - indeed perhaps even more existentially pervasive, on account of the very importance accorded to questions of property and labour by early republican thinkers.

Thus in E. P. Thompson's account the early years of Owenism and Chartism:

reveal a passing beyond the characteristic outlook of the artisan, with his desire for an independent livelihood 'by the sweat of his brow', to a newer outlook, more reconciled to the new means of production, but seeking to exert the collective power of the class to humanize the environment - by this community or that cooperative society, by this check on the blind operation of the market-economy, by this legal enactment, that measure of relief of the poor. (Thompson 1962: 910-13)

Gareth Stedman Jones has rightly warned against teleological readings of nineteenth century radicalism as the inessential or superficial expression of a deeper class antagonism (Stedman Jones 1983). But the writings of the Chartist period reveal an acute awareness of the developing interrelation of legal domination and economic exploitation, and of capitalism -in the form it was then taking - as a profoundly political construction. And the corresponding interconnection of republican self-governance and collective economic regulation was pursued and developed through William James Linton's English Republic and the early formation of the Social Democratic Federation.

Similar continuities can be seen in the development of socialism in France. In the 1840s Pierre-Joseph Proudhon, an ardent (if idiosyncratic) follower of Rousseau, justified his denunciation of property as a refusal of arbitrary power, in both political and economic forms. "The proprietor, the robber, the hero, and the sovereign (for all these titles are synonymous) each imposes his will as law and suffers neither contradiction nor control ... property necessarily engenders despotism, the government of arbitrary 
will, the reign of libidinous pleasure'. For Proudhon, government was a matter of 'public economy' - 'its object is production and consumption, the distribution of labour and products' - but this objective of economic regulation was obstructed and undermined by the existence of private proprietors - 'despotic kings ... in proportion to their acquisitive faculties' (Proudhon 1994: 210). Proudhon's translation of republican into socialist principle is bold and explicit: 'since property is the great cause of privilege and despotism, the form of the republican oath should be changed. Instead of saying, "I swear hatred to royalty", an applicant to a secret society should henceforth say, "I swear hatred to property" (Proudhon 1994: 158-9). Even the later incursion of Marxist thought into French socialism did not prevent what Tony Judt describes as 'a long period of overlap during which the socialism of Jaurès and Blum combined Marxist social analysis and final goals with democratic or republican methods drawn from the earlier tradition' (Judt 1986: 7).

And in fact the direct transposition of republican concerns into the domain of the economy is right at the heart of Marx's thinking, though this was all but invisible in the orthodox versions of Marxism that dominated the Second International in the latter years of the nineteenth century. Marx's early thinking was much exercised by Prussia's social and political backwardness, and in particular the persistence of neo-feudal relations of personal lordship and dependence (Herrschaft). ${ }^{6}$ But his thought develops as a critical interrogation of the notion that the market liberates individuals from feudal ties, arguing that the formal independence of the labourer as free seller of his own labour-power is subverted by the background conditions that leave him little choice but to submit again and again to his own exploitation. 'In the developed system of exchange (and this semblance seduces the democrats), the ties of personal dependence, of distinctions of blood, education, etc, are in fact exploded, ripped up . . . and individuals seem independent', Marx writes in the Grundrisse of 1858, as if in direct rejoinder to Smith. 'But they appear thus only for someone who abstracts from ... the conditions of existence within which these individuals enter into contact ... The abstraction, or idea, however, is nothing more than the theoretical expression of those material relations which are their lord and master' (Marx 1973: 163-4). For Marx, then, the fact that we are dominated by an impersonal force, 'the market', or 'the economy' or 'capital', makes it no less arbitrary a tyranny. Marx's occasional invocations of the abstract communist ideal suggest a utopian yet luminous redrawing of Rousseau's social contract to take in the full range and depth of our economic interactions: 'an association of free men, working with the means of production held in common, and expending their many different forms of labour-power in full self-awareness as one single social labour force' (Marx 
1990: 171). And his accounts of the more concrete if partial advances of the working-class movement present them unambiguously as early steps towards collective economic self-government: as they win the battle for legislation to regulate the conditions of their labour, the working class 'transform that [governmental] power, now used against them, into their own agency. They effect by a general act what they would vainly attempt by a multitude of individual efforts' (Marx 1974: 89).

The Chartists, Proudhon and Marx are offered here only as brief illustrations of an uneven but unmistakeable trend that can be followed through the nineteenth-century left - as Eley puts it, a delinking of "calls for democracy' from 'ideals of small-scale organization, local community, and personal independence' that were becoming 'far harder to sustain':

That is, under conditions of capitalist industrialisation the implications of demanding popular sovereignty became profoundly transformed. Gradually and unevenly, democracy became linked to two new demands: an economic analysis of capitalism and a political program for the general reorganizing of society ... It was in that moment of transformation that people began exploring the possibilities of collective ownership and socialism. (Eley 2002: $18-20)$

\section{The political economy of contemporary neo-republicanism}

The history of the twentieth century is to some extent the history of the ultimate failure or defeat of those attempts to 'make democracy social' as Eley puts it. The full-blown version of collective economic control through centralised planning certainly proved unable to either meet people's developing material needs or meaningfully actualise the impulse to economic self-government that lay behind its initial formulation. More partial 'social democratic' variants, which left significant domains of market relations and private ownership in place but sought to correct their tendency to centralise social and economic power through measures of partial decommodification, corporate representation and selective socialisation, also stand accused of depressing economic dynamism and impeding genuine empowerment.

It is against this background that the left has retreated from economic collectivism and sought to anchor its objectives more firmly on the ground of individual autonomy and democratic participation. This, of course, is where classical republican arguments come into their own. But this still raises the question of whether contemporary capitalism furnishes the social and economic conditions for individual and collective self-government - or whether the new republican revival entails its own, distinctive agenda for economic and social reform. In so far as contemporary discussions have 
pursued such questions, they have tended to converge on a cluster of ideas and proposals that I think can reasonably be brought under the heading of a 'property-owning democracy'.

The common impulse behind these schemes is the thought that appropriately designed mechanisms of redistribution and regulation can perform a task similar to the classical republicans' 'agrarian law' for modern commercial economies - ensure that every citizen has enough private property to secure their independence, yet never so much that they might be capable of dominating others. As Gareth Stedman Jones has shown, we can trace early versions of this programme to the proposals of Thomas Paine and Antoine-Nicolas Condorcet for systems of universal social insurance that could provide every member of society with the security and independence they needed to develop the capacity and the virtues of active citizenship (Stedman Jones 2004). More recently the idea has been given a new outing by John Rawls, who, despite his customary classification as the most influential liberal thinker of the late twentieth century, in fact claimed in his later writings to be closer to the republican tradition (Rawls 2001). Drawing on the work of the post-war social democratic economist James Meade, Rawls goes on to argue that the most appropriate economic arrangements for the realisation of his political ideal is not, as is commonly assumed, a form of 'welfare-state capitalism', but a 'property-owning democracy' in which 'background institutions ... work to disperse the ownership of wealth and capital, and thus to prevent a small part of society from controlling the economy, and indirectly, political life as well'. By ensuring 'the widespread ownership of productive assets and human capital' such an economy might 'put all citizens in a position to manage their own affairs on a footing of a suitable degree of social and economic equality' (Rawls 2001: 139, quoted in Dagger 2006: 160-1).

This need not be so abstract as the Rawlsian style of philosophy might lead us to assume. Indeed, it can be seen to dovetail very closely with contemporary policy innovations aimed precisely at advancing the left's ideals of equal autonomy and participation in a way that escapes the impasse of twentieth-century social democracy. Stuart White in particular has developed a fascinating line of work that links the political aspirations of republicanism and the 'property-owning democracy' with the real-world experiments in 'citizens' income', 'asset-based welfare' and 'stakeholderism' being developed by centre-left governments around the world today (White 2001, 2003; see also Raventós 2007; Paxton 2003; Ackerman and Alstott 1999). The broad argument is that even if we must give up the attempt to exercise economic self-governance by submitting our productive activities to collective regulation and control, we can combine the efficiency and dynamism of markets with the social and economic equality 
necessary to underpin a genuinely republican politics by redistributing concentrations of private wealth (through inheritance tax, for example) to ensure that no individual ever becomes completely dependent on a particular form of employment and that all have the means to participate in the economic, social and political life of a society on broadly equal terms. To put the argument in simple, concrete terms: if we all knew we had a modest independent income and/or financial nest egg to fall back on, we would feel more emboldened to walk out of a demeaning or restrictive job, to take time out for educating ourselves, to start our own business, to engage in community activism, to pursue our artistic leanings, to publish our own newspaper (or, more likely today, maintain our own online 'blog'); as well as being able to exercise some democratic rights, or a degree of direct control, over the future economic development of my society by virtue of being a shareholder or investor.

These are exciting ideas and it is easy to see how they might form the basis for a revitalised and repopularised left project. But I think it is also appropriate that we ask hard questions about how far they can go, and what problems still remain with respect to the economic conditions for universal self-government. In particular, the history of the left in the nineteenth century should at least give us pause to consider whether the developing characteristics of modern economies upon which older republican programmes foundered might still pose a challenge for any attempt to recreate a 'property-owning democracy' for the twenty-first century.

The nub of the issue is, I think, whether the depth and extent of our economic interdependence, and the degree of socialisation of productive processes this entails, must render any attempt to secure a meaningful 'independence' through individual private property entitlements at risk of inadequacy and marginalisation. Practically speaking, there are surely grounds to doubt that the decentralisation of property entitlements can be matched by an equal decentralisation of productive processes - so that selfemployment or small-scale producer cooperatives become the norm. If that is granted, then the reality for many citizens will be that their 'property' consists of a 'stake' in larger productive enterprises - a situation similar to the position of today's employees of John Lewis, for example, or even that of the large portion of the workforce with an occupational or personal pension invested (usually through some intermediary) in contemporary stock markets. There is no question that the democratising potential of such incipient stakeholderism can and should be pushed much, much further (see Davis et al., 2006). But the challenge this presents is, I suggest, not actually so different from that faced by earlier forms of economic collectivism. This is the challenge of pooling our productive resources and capacities in forms of cooperative and socialised production that are sufficiently 
sophisticated to meet our diverse needs, and at the same time accommodate our aspirations for forms of work that can be experienced as genuine forms of self-expression and self-rule, rather than alienating or oppressive impositions. This is the task that history has set us. It is perhaps a far more difficult task than most early socialists imagined. But I don't think it is one that republicanism allows us to bypass or defer.

\section{Conclusion}

The danger of the 'property-owning' ideal, then, is that its signature ideal of individual independence may seem to offer a false escape alley from the dangers and difficulties of building forms of collective action and democratic self-rule that do not become distant, remote, unrepresentative and unresponsive. This is by no means to dismiss the value of the reforms that have been proposed under this banner, but rather to suggest that they might be seen as reinforcing accompaniments, rather than radical alternatives, to more direct efforts at collective control over our economic life such as trade union representation and industrial democracy (discussed in this volume in Chapter 14), government regulation and intervention, and, indeed, public ownership and planning.

But I want to end by making a point of disowning what I fear may be an unfortunate impression given by my argument - that of a progressivist teleology that holds up economic collectivism as a higher ideological or social form than republicanism. Republicanism is back on the agenda precisely because the economic collectivisms that succeeded it failed, or decayed. And here I want to add an additional argument for the contemporary value of the republican tradition. The progressivism of the Enlightenment and the philosophies of history that it spawned are often traduced and I think too glibly dismissed. But it is undoubtedly the case that they imbued social and political thinkers, on the left in particular, with sometimes unhelpful habits of thought. Here we can indeed return to the abiding concern of classical republicanism with the instability of any institutional or cultural achievement and the cyclical tendency for republics to rise and fall. The collective institutions of the twentieth century did lose their life, became captured by factions and detached from the lives of those they meant to serve. The sense of loss this engendered has been disorientating and disabling for the left, which had over decades become used to the idea that history was on its side. But an instructive leaf can be taken from the book of republican writers who knew all too well the propensity of their institutions to decline and die, and regarded their political mission as one of inculcating the virtues and the practices that could renew and sustain new forms of collective action. 


\section{Notes}

1 Numerous people have helped me develop the arguments laid out here, but I wish to extend particular thanks to Ben Jackson, Nina Fishman and John Callaghan for invaluable advice and encouragement on earlier drafts, and to Stuart White, whose work on these issues has been a central source and stimulus for my own thinking.

2 The relevant literature here is voluminous but a representative and up-to-date sample can be found in Laborde and Maynor 2008.

3 Pettit writes that "while it is true that republican thinkers in general regarded democratic participation or representation as a safeguard of liberty, not as its defining core, the growing emphasis on democracy did lead some individuals away from traditional alignments and towards the full populist position of holding that liberty consists in nothing more or less than democratic self-rule. However republican and attractive his views in other respects, Rousseau is probably responsible for having given currency to such a populist view' (Pettit 1999: 30).

4 It may be that we forget how much the person and institution of the monarch once symbolised and embodied this more substantive sense of shared identity and common enterprise, because our remaining monarchs today exercise such a marginal and formal role. I am grateful to Nina Fishman for suggesting this point.

5 I am grateful to John Callaghan for suggesting this point to me.

6 See Breckman 1999. On the pivotal importance of this concept for Prussian conservative thought, see Berdahl 1988.

\section{References}

Ackerman, B. and Alstott, A. (1999) The Stakeholder Society (New Haven: Yale University Press).

Berdahl, R. M. (1988) The Politics of the Prussian Nobility: the Development of a Conservative Ideology 1770-1848 (Princeton: Princeton University Press).

Bevir, M. (2000) 'Republicanism, socialism, and democracy in Britain: the origins of the radical left', Journal of Social History, 34 (2).

Biagini, E. F. and Reid, A. J. (1991) 'Currents of radicalism, 1850-1914', in Biagini and Reid (eds), Currents of Radicalism: Popular Radicalism, Organised Labour and Party Politics in Britain, 1850-1914 (Cambridge: Cambridge University Press).

Breckman, W. (1999) Marx, the Young Hegelians, and the Origins of Radical Social Theory: Dethroning the Self (Cambridge: Cambridge University Press).

Dagger, R. (2006) 'Neo-republicanism and the civic economy', Politics, Philosophy and Economics, 5 (2).

Davis, S., Lukomnik, J. and Pitt-Watson, D. (2006) The New Capitalists: How Citizens are Reshaping the Corporate Agenda (Cambridge, MA: Harvard Business School Press). 
Eley, G. (2002) Forging Democracy: the History of the Left in Europe, 1850-2000 (Oxford: Oxford University Press).

Judt, T. (1986) Marxism and the French Left: Studies on Labour and Politics in France 1830-1981 (Oxford: Clarendon Press).

Laborde, C. and Maynor, J. (2008) Republicanism and Political Theory (Oxford: Wiley-Blackwell).

McNally, D. (1993) Against the Market: Political Economy, Market Socialism and the Marxist Critique (London: Verso).

Marquand, D. (2008) ‘England and Europe: two ‘Es that lie in wait for Brown's Britishness', published on Open Democracy News Analysis: www.opendemocracy.net, 1 February.

Marx, K. (1973) Grundrisse, trans. M. Nicolaus (London: Penguin Books).

Marx, K. (1974) 'Documents of the First International: 1864-70', in The First International and After: Political Writings: Volume 3, ed. D. Fernbach (London: Penguin Books).

Marx, K. (1990) Capital: Volume I, trans. B. Fowkes (London: Penguin Books).

O'Neill, M. (2008) 'Liberty, equality and property-owning democracy', Manchester Papers in Political Economy: www.socialsciences.manchester.ac.uk/cspe/publications/wp/documents/ONeillWP02-08.pdf (accessed 15 July 2008).

Paine, T. (1998) Rights of Man, Common Sense and other Political Writings, ed. Mark Philp (Oxford: Oxford University Press).

Paxton, W. (ed.) (2003) Equal Shares? Building a Progressive and Coherent AssetBased Welfare Policy (London: Institute for Public Policy Research).

Pettit, P. (1999) Republicanism: a Theory of Freedom and Government (Oxford: Oxford University Press).

Proudhon, P. J. (1994) What is Property? (Cambridge: Cambridge University Press).

Raventós, D. (2007) Basic Income: the Material Conditions of Freedom (London: Pluto Press).

Rawls, J. (2001) Justice as Fairness: a Restatement (Cambridge, MA: Harvard University Press).

Rousseau, J. J. (1997) The Social Contract and Other Later Political Writings, ed. V. Gourevitch (Cambridge: Cambridge University Press).

Skinner, Q. (1997) Liberty Before Liberalism (Cambridge: Cambridge University Press).

Spinoza, B. de (2005) A Theologico-Political Treatise and A Political Treatise, ed. R. H. M. Elwes (London: Dover).

Stedman Jones, G. (1983) 'Rethinking Chartism', in Languages of Class: Studies in English Working Class History 1832-1982 (Cambridge: Cambridge University Press).

Stedman Jones, G. (2004) An End to Poverty? A Historical Debate (London: Profile Books).

Thompson, E. P. (1962) The Making of the English Working Class (London: Penguin Books).

White, S. (2001) 'Rediscovering republican political economy', Citizen's Income 
Newsletter, 1: www.citizensincome.org/filelibrary/Archived\%20Newsletters/ 2001\%20Issue\%201.pdf (accessed 15 July 2008).

White, S. (2003) The Civic Minimum (Oxford: Oxford University Press).

White, S. (2007) 'Is republicanism the left's "big idea”?' Renewal, 15 (1).

Winch, D. (2002) 'Commercial realities, republican principles', in M. van Geldern and Q. Skinner (eds), Republicanism: a Shared European Heritage, vol. 2 (Cambridge: Cambridge University Press). 